ZOOLOGIA 27 (4): 523-532, August, 2010

doi: $10.1590 /$ S1984-46702010000400004

\title{
Reproduction of the flatfish Achirus lineatus (Pleuronectiformes: Achiridae) in Paranaguá Bay, state of Paraná, a subtropical region of Brazil
}

\author{
Elton C. de Oliveira' \& Luís Fernando Fávaro'1,2
}

\author{
${ }^{1}$ Laboratório de Reprodução e Comunidade de Peixes, Setor de Ciências Biológicas, Universidade Federal do Paraná. \\ Caixa Postal 19031, 81531-990 Curitiba, PR, Brazil. \\ 2 Corresponding author. E-mail: lufavaro@ufpr.br
}

\begin{abstract}
The present study characterizes the oogenesis and the ovarian maturation scale, and determines the reproductive period, type of spawning, recruitment period, and population variations in the reproductive process of the flatfish Achirus lineatus (Linnaeus, 1758). Specimens were sampled on a monthly basis in the shallow near shore area of the Paranaguá Bay, state of Paraná, Brazil, from March 2006 to February 2007. The specimens collected were measured for morphometric data (total length and total weight) and their gonads were exposed for macroscopic evaluation. The gonads were subsequently removed, weighed and processed for microscopic analyses. Six phases of the ovarian follicle development were defined, as well as five ovarian development stages. Growth patterns differed between the sexes: negative allometry for females and positive allometry for males. Based on the seasonal assessments of the distribution of individual GSI values, the distribution of stages of gonadal development, individual body size, sex ratio, the ratio of juveniles to adults, and histological examination of the ovaries, reproduction was found to occur in the spring (spawning in batches), and recruitment in the autumn. These results show that $A$. lineatus is an estuarine-resident species that uses the study area for reproduction and recruitment, providing an argument in favor of the need to conserve the estuarine environment in order to preserve stocks.
\end{abstract}

KEY WORDS. Oogenesis; maturity scale; reproductive period; type of spawning; sex ratio.

The study of the reproductive process of fish species is extremely important for two reasons. First, reproduction is a key aspect in the perpetuation of a species; second, such studies provide data on how fish use a given system or area, which is useful to fisheries and aquaculture management agencies (DIAs et al. 1998).

The fishes popularly known as "flatfishes" encompass many commercially important species, which are heavily exploited by the fishing industry and aquaculture (PARDO et al. 2005).

Flatfish are considered by BERENDZEN \& DIMMICK (2002) to be monophyletic and very specialized; the group exhibits quite unique morphologic features (Mendonça \& Araujo 2002). They belong in the widely distributed order Pleuronectiformes, which includes 570 species, 123 genera and 11 families (Nelson 1994). Flatfish occur from arctic and subantarctic regions (Bailey et al.2008) to tropical and subtropical environments (GUEDES \& Araujo 2008). Approximately three-quarters of all known flatfish species inhabit tropical and subtropical regions (PARDO et al.2005).

In Brazil, flatfish are widely distributed along the coast. They can be found in larger numbers in estuarine and marine environments, though they also occur in lacustrine regions
(Figueiredo \& Menezes 2000). Given the quality of their meat, flatfish are economically very important (Mendonça \& Araujo 2002) and have considerable market potential.

Although studies on the reproductive biology (CHAVEs \& VENDEl 1997, Dias et al. 2005), feeding ecology (LunARDON-BRANCO \& Branco 2003, Guedes et al. 2004, Guedes \& Araujo 2008) and population composition (Mendonça \& Araujo 2002) have been conducted on some species of Brazilian coastal flatfish, little is known about the autoecological parameters of most species occurring in the country.

The occurrence, abundance (BARLETTA et al. 2005, QUEIROZ et al. 2006, AzEvedo et al. 2007), trophic partitioning of resources (Guedes \& Araujo 2008), phylogenetics (Pardo et al. 2005) and cytogenetics (AzEvedo et al. 2007) of the flatfish Achirus lineatus (Linnaeus, 1758), subject of the present study, have been previously investigated. This medium-sized species (maximum length of $23 \mathrm{~cm}$ ) is distributed from Florida to northern Argentina, being found in sandy bottoms, especially in marine and estuarine environments, where individuals live buried or camouflaged by their body colour (Figueiredo \& MENezes 2000).

Even though $A$. lineatus occurs frequently in the estuaries of the state of Paraná, the species is not considered abundant (Queiroz et al. 2006, Schwarz et al. 2006). Information on 
the biology (diet, reproduction and population dynamics) of A. lineatus is absent from the literature and is badly warranted, since it is key to understanding the life cycle and area use by this species.

The present study (1) characterizes the phases of ovarian follicle development and the stages of ovarian maturation; (2) determines the growth pattern, reproductive period, type of spawning and recruitment period; (3) evaluates the seasonal fluctuations in body size of individuals, sex ratio and ratio of juveniles to adults for both females and males of $A$. lineatus in the Paranaguá Bay, state of Paraná, Brazil.

\section{MATERIAL AND METHODS}

The Paranaguá Bay is part of the estuarine complex of Paranaguá (northern coast of Paraná). It is the largest bay in this estuarine system. The bay is approximately $45 \mathrm{~km}$ long, with a maximum width of $7 \mathrm{~km}$ and a mean depth of $5.4 \mathrm{~m}$ (maximum $23 \mathrm{~m}$ ). Some 30 islands are scattered about in the area, the most important being: Ilha das Cobras; Ilha dos Valadares; Ilha das Peças; Ilha do Mel; Ilha da Cotinga; and Ilha Rasa da Cotinga (IPARDES 2001). The last one was chosen as the location of the sampling sites.

Ilha Rasa da Cotinga is located at coordinates $25^{\circ} 30^{\prime} 05^{\prime \prime} \mathrm{S}$, $48^{\circ} 28^{\prime} 12^{\prime \prime} \mathrm{W}$ and $25^{\circ} 32^{\prime} 44^{\prime \prime} \mathrm{S}, 48^{\circ} 24^{\prime} 02^{\prime \prime} \mathrm{W}$ in the euhaline sector of the Paranaguá Bay (LANA et al. 2001). The northern portion of the island faces the Galheta canal, the main access to the Paranaguá and Antonina harbours. Located very close to the second largest active harbour in Brazil, the Paranaguá harbour, our study area (and the remaining estuarine region) is strongly influenced by anthropogenic activities (urban and farming) (Fig. 1)

According to the Köppen classification, the climate in the region is mesothermal humid subtropical with warm summers and no well-defined dry season (Cfa). The mean air temperature in the warmest month is above $22^{\circ} \mathrm{C}$, and below $18^{\circ} \mathrm{C}$ in the coldest month (MAACK 1981). The mean humidity of the region is $85 \%$, with mean annual rainfall of $2,500 \mathrm{~mm}$ (LANA et al. 2001).

Collections took place monthly from March 2006 to February 2007, at two sampling sites located in the northern part of Ilha Rasa da Cotinga (Fig. 1).

Specimens of A. lineatus were sampled in the shallow nearshore area (depth ranging from 3-12 m) with 15-minute otter trawl surveys at each sampling site. The trawl net had the following dimensions: $8 \mathrm{~m}$ mouth, $7 \mathrm{~m}$ cod end, $1.5 \mathrm{~cm}$ mesh between adjacent knots and otter boards weighing approximately $8 \mathrm{~kg}$.

In the laboratory, specimens were identified (FigueIredo \& Menezes 2000) and the following morphometric data were recorded: length (Lt) $(\mathrm{cm})$ and total weight $(\mathrm{Wt})(\mathrm{g})$.

Following ventral transection, the gonads of the individuals were exposed and examined macroscopically for sex and

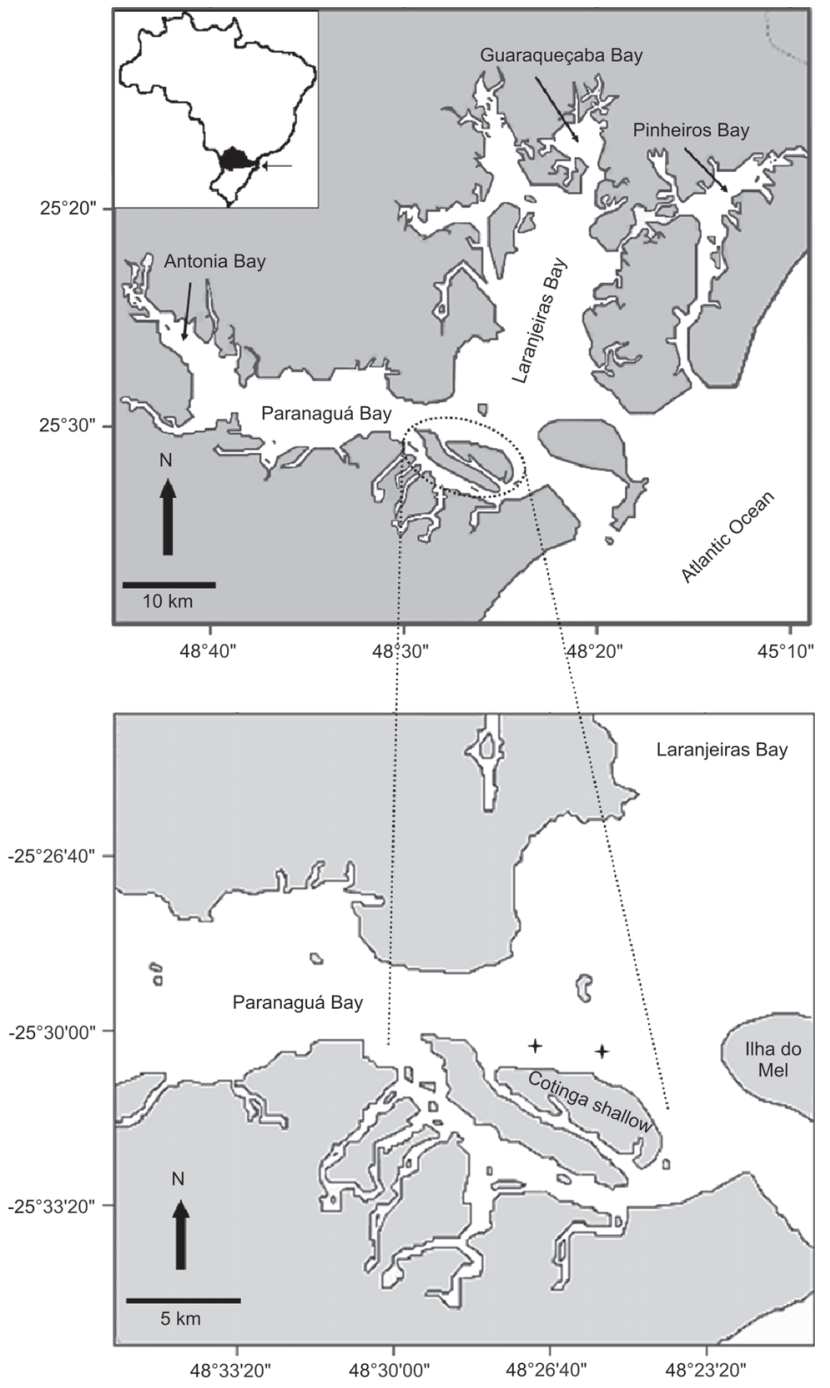

Figure 1. Map of the estuarine complex of Paranaguá, state of Paraná. The study area and the sampling sites are indicated in the detailed map.

gonadal development determinations, according to the ovarian maturity scale proposed by VAzzoler (1996) and the testicular maturity scale proposed by Gomes \& Araujo (2004). The gonads were then removed and weighed. Some were fixed in ALFAC (ethanol, formalin and acetic acid) for 20 hours. They underwent routine processing for the preparation of histological slides, which were stained with hematoxylin-eosin for microscopic analysis. They were then analyzed under the light microscope in order to confirm the macroscopic determination of the stages of gonadal development. Voucher specimens were deposited in the fish collection at the Museu de História Natural do Capão da Imbuia (MHNCI) (Achirus lineatus: MHNCI 12329). 
In the present study, only the microscopic descriptions of oogenesis and the female maturity scale were used to characterise the stages of gonadal development. According to West (1990), it is easier to characterise these through the female gonads. The latter also yield more accurate estimates of timing and type of spawning, in addition to exhibiting greater temporal changes in weight when compared to males.

The phases of oogenesis were determined by comparing the size of the ovarian follicles, the affinity for hematoxylineosin, the appearance of follicular cells and the vitelline membrane, and the presence of cytoplasmic vesicles and vitellus granules. The maturity scale is based on the composition and frequency of the ovarian follicle phases.

Due to the small number of specimens obtained monthly, we grouped our samples into seasons for analysis, and thus provide more consistent results for $A$. lineatus, a species whose biology is still unknown to researchers.

The weight-length relationship, used to corroborate male and female reproductive aspects, was estimated according to the assumptions of the potential model: $\mathrm{Wt}=\mathrm{a} \cdot \mathrm{Lt}^{\mathrm{b}}$, where " $\mathrm{a}$ " is the linear coefficient, and " $b$ " is the angular coefficient. The linear and angular coefficients were determined through the minimumsquare method. The weight-length relationship equations, estimated for the sexes (grouped and in separate,) were compared using two methods: 1) the confidence interval method for visual comparison of the slope of the straight lines; 2) Student's ttest (ZAR 1999). In addition, both methods were used to compare the value of the slope of the straight line for each sex with the value of the hypothetical model of isometric growth (3.0).

The Gonadosomatic Index (GSI), expressed by the formula: $\mathrm{GSI}=(\mathrm{Wg} / \mathrm{Wt}) \times 100$, in which $\mathrm{Wg}=$ gonad weight and $\mathrm{Wt}=$ total weight of the individual, was applied to each individual (females and males separately). Thus, it was possible to assess the period with the highest frequency of individuals having the highest GSI values. This period was assumed to correspond to the reproductive period.

The percentage frequency distribution of the stages of gonadal development was determined for females and males separately. This analysis employed the histologically confirmed stages, which were defined as the five stages of gonadal development: immature (IMT); maturing (MTG); mature (MAT); partially spawned (females) (PSP); spawned and/or recovered (females)/spent (males) (SPT).

The size of individuals was assessed through the variations in the means for total length (Lt) and total weight (Wt) of individuals (grouped sexes). The seasons of the year were taken as the treatments, and the individuals the replicates; thus, a parametric analysis of variance (ANOVA) was applied, followed by Tukey's post hoc test, in order to identify which means differed throughout the year. In order for the ANOVA to be applied, the assumptions of normality and homogeneity of the variances were verified through the Shapiro-Wilk test and the Levene test, respectively (QuinN \& KeOUgh 2002).

Sex ratio was estimated through the seasons of the year, and possible differences as to the expected ratio of 1:1 were assessed through the $\chi^{2}$ (Chi-square) test, with a degree of freedom of 1 and significance of $0.05\left(\chi^{2}>3.84\right)$, according to VAZzoler (1996).

The analysis of the ratio of juveniles to adults was conducted with pooled data for males and females. Individuals exhibiting gonads in the immature (IMT) stage were considered juveniles, and those presenting gonads in any other development stage (maturing (MTG), mature (MAT), partially spawned (PSP) and spent/empty (SPT)) were considered as adults. The $\chi^{2}$ test estimated possible differences in the distribution of juveniles and adults throughout the seasons of the year.

The seasons of the year were defined as autumn (April to June), winter (July to September), spring (October to December) and summer (January to March).

\section{RESULTS}

Through histological analysis, six phases of ovarian follicle development were established. Their main characteristics are summarised in table I.

According to the composition and frequency of the phases of the ovarian follicle, five stages of ovarian development were established (Tab. II).

Table I. Description of the main features defining each phase of ovarian follicle development in A. lineatus in the Paranaguá Bay, state of Paraná.

\begin{tabular}{|c|c|c|c|c|}
\hline \multirow{7}{*}{ Ovarian follicles } & Phase I (oogonia) & \multicolumn{3}{|c|}{ Small cells with scant cytoplasm, a large nucleus and a single nucleolus (Fig. 3) } \\
\hline & & Cytoplasm (oocyte) & Vitelline membrane & Follicular cells \\
\hline & Phase II (Figs 3-4) & Basophilic & Absent & \multirow{5}{*}{ Squamous } \\
\hline & Phase III (Fig. 4) & Cytoplasmic vesicles & \multirow{4}{*}{ Present } & \\
\hline & Phase IV (Fig. 4) & Cytoplasmic vesicle and vitellus granules & & \\
\hline & Phase V (Figs 5-6) & Vitellus granules & & \\
\hline & Phase VI (Fig. 6) & Hyalinised & & \\
\hline
\end{tabular}

Empty and atretic follicles were not considered development phases of the ovarian follicles, but rather structures derived from the process of oogenesis. 
Table II. Description of the five stages of ovarian development observed in A. lineatus in the Paranaguá Bay, state of Paraná. The description is based on the frequency and composition of the phases of the ovarian follicle.

\begin{tabular}{ll}
\hline \multicolumn{1}{c}{ Stages } & \multicolumn{1}{c}{ Microscopic characteristics } \\
\hline Immature (IMT) & Ovarian follicles in phases I and II (Fig. 2) \\
Maturing (MTG) & Ovarian follicles in phases I, II, III and IV (Fig. 4) \\
Mature (MAT) & Predominance of ovarian follicles in phase V and/or VI (Figs 5-6) \\
Partially spawned (PSP) & Empty follicles along with phases III, IV and V (Fig. 7) \\
Spawned/Recovered (SPT) & Empty follicles along with ovarian follicles in phases I and II (Fig. 8) \\
\hline
\end{tabular}

A total of 179 specimens of $A$. lineatus were collected during the study period (121 females, 48 males and 10 very small specimens classified as immatures and of undefined sex). The unsexed specimens were excluded from the following analyses: weight-length relationship, seasonal distribution of individual GSI values and sex ratio.

Histological analyses made it possible to observe all stages of ovarian development. Partially spawned ovaries were found; as a result, spawning was characterised as batch spawning (Fig. 7). Hyalinised follicles (in mature ovaries) and residual bodies (in postspawning ovaries) were also observed in the histological sections (Figs 6-8, respectively).

The confidence interval and Student's t-test, used to compare the slopes of the straight lines produced by the weightlength relationship, showed similar results. Significant differences were found between the slope of the straight line for females and for males $\left(t_{169}=4.21, p<0.05\right)$. Females exhibited negative allometric growth $(b=2.91)$, while males had positive allometric growth $(b=3.15)$, both confirmed when compared with the hypothetical model of isometric growth $\left(\mathrm{t}_{121}=\right.$ $-3.76, \mathrm{p}<0.05 ; \mathrm{t}_{48}=4.63, \mathrm{p}<0.05$, respectively). The weightlength relationship graph also demonstrated that females achieve larger sizes than males (Fig. 9). The analysis of the results demonstrates that there are gender differences in the size of individuals.

Analysis of the distribution of individual GSI values showed that the greatest gonadal development occurred in the spring (Figs 10 and 11) for both sexes.

For females, the analysis of the seasonal percentage frequency distribution of the gonadal development stages, confirmed by histological examination, showed the predominance of mature specimens in the spring, partially spawned and spawned in summer, spawned in autumn, and an increase in the number of immature specimens in the winter. For males, an increase was found in the number of maturing individuals in the spring. Other findings were the preponderance of spent individuals in the summer and a predominance of juvenile specimens in the autumn and winter. Spent males and partially spawned and spawned females were collected throughout the study period (Figs 12 and 13).

A seasonal assessment of the size of $A$. lineatus individu- als showed a temporal variation $\left(\mathrm{Lt}: \mathrm{F}_{3.179}=7.25\right.$, $\mathrm{p}<0.05$; $\mathrm{Wt}$ : $\mathrm{F}_{3 ; 179}=7.06, \mathrm{p}<0.05$ ), with the largest individuals occurring during the summer, followed by a significant decline in mean specimen size during the autumn and especially during the winter. In the spring, an increase was observed in the size of individuals in relation to the previous season (Figs 14 and 15). Even though females predominated year-round, sex ratio assessments revealed that significant sex ratio differences occurred only in spring and summer, with approximately three females for each male (Tab. III).

Table III. Seasonal sex ratio of $A$. lineatus specimens in the Paranaguá Bay, state of Paraná. * significant values ( $\mathrm{df}=1, \mathrm{p}<0.05$ ).

\begin{tabular}{lccc}
\hline \multicolumn{1}{c}{ Seasons } & Females & Males & $\chi^{2}$ \\
\hline Autumn & 16 & 12 & 0.57 \\
Winter & 9 & 5 & 1.14 \\
Spring & 65 & 20 & $23.82^{*}$ \\
Summer & 31 & 11 & $9.52^{*}$ \\
\hline
\end{tabular}

The results of the ratio of juveniles to adults showed that adult individuals predominated in the autumn, and (especially) in the spring and the summer. The last two seasons also accounted for the highest values of individual GSI, the highest occurrences of mature individuals, and partially spawned and spawned/spent and larger specimens. Catches of juveniles were more frequent in autumn, while numerical predominance occurred in winter (Fig. 16).

\section{DISCUSSION}

The development of the ovarian follicles of A. lineatus followed the same basic growth patterns already described for other teleosts. According to Jobling (1995) and Вrooks et al. (1997), even though the growth patterns of teleost oocytes are similar, the reproductive strategies and tactics of the included groups vary to a great extent. Six stages of ovarian follicle development have been characterised for estuarine and/or ma- 




Figures 2-8. Histological sections of the ovaries of Achirus lineatus, HE staining: (2) immature ovary, scale $450 \mu \mathrm{m}$; (3) immature ovary, oogonia (arrow) and ovarian follicle in phase II (P II), scale $45 \mu \mathrm{m}$; (4) maturing ovary, ovarian follicle in phase II (P II), III (P III) and IV (P IV), vitelline membrane (star), scale $90 \mu \mathrm{m}$; (5) mature ovary, ovarian follicles in phase IV (P IV) and V (P V), scale 180 $\mu$ m; (6) mature ovary, ovarian follicles in phase IV (P IV), V (P V) and VI (P VI), scale $180 \mu \mathrm{m}$; (7) partially spawned ovary, ovarian follicle in phase III (P III), IV (P IV), V (P V) and empty follicles (yellow arrow), scale $180 \mu \mathrm{m}$; (8) recovered ovary, ovarian follicles in phase II and residual bodies (red arrows), scale $180 \mu \mathrm{m}$. 


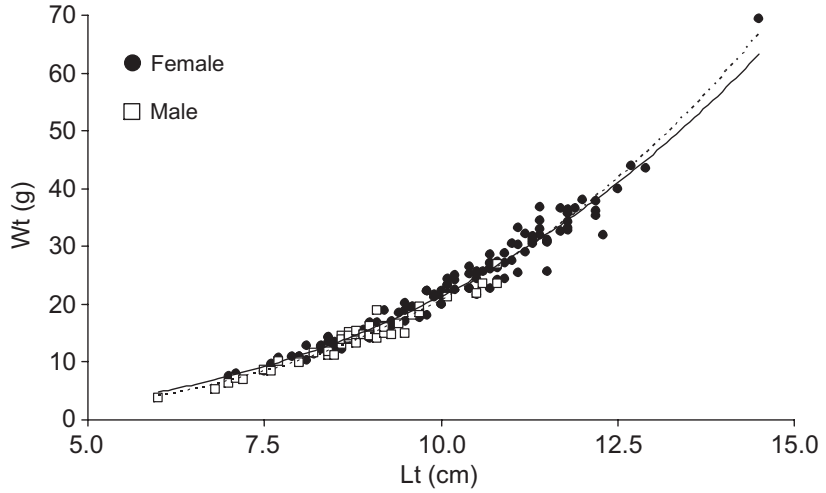

Figure 9. Weight-length relationship for A. lineatus females and males in the Paranaguá Bay, state of Paraná. The dashed line shows the slope of the straight line for males and the full line shows the slope of the straight line for females. rine fishes, contrasting with the five stages found for freshwater species (VAzzoler 1996). This discrepancy is due to pre-ovulation hydration, observed only in marine and estuarine fishes, which present coalescence of the vitellus granules and a substantial increase in the volume of the ovarian follicle. According to CHAves (1989), pre-ovulation hydration was is a result of adaptive convergence.

The detection of mature ovaries with hyalinised follicles is a powerful indicator that the study area serves as a spawning site for A. lineatus, since oocyte hyalinisation occurs just prior to their release into the environment (PatiÑo \& SulLivan 2002). Thus, based on the information above, and also on the fact that individuals of $A$. lineatus were captured in all stages of gonadal development and throughout the study period, this flatfish species can be classified as estuarine-resident. According to BLABER (2002), an estuarine-resident species goes through its entire life cycle in estuaries.
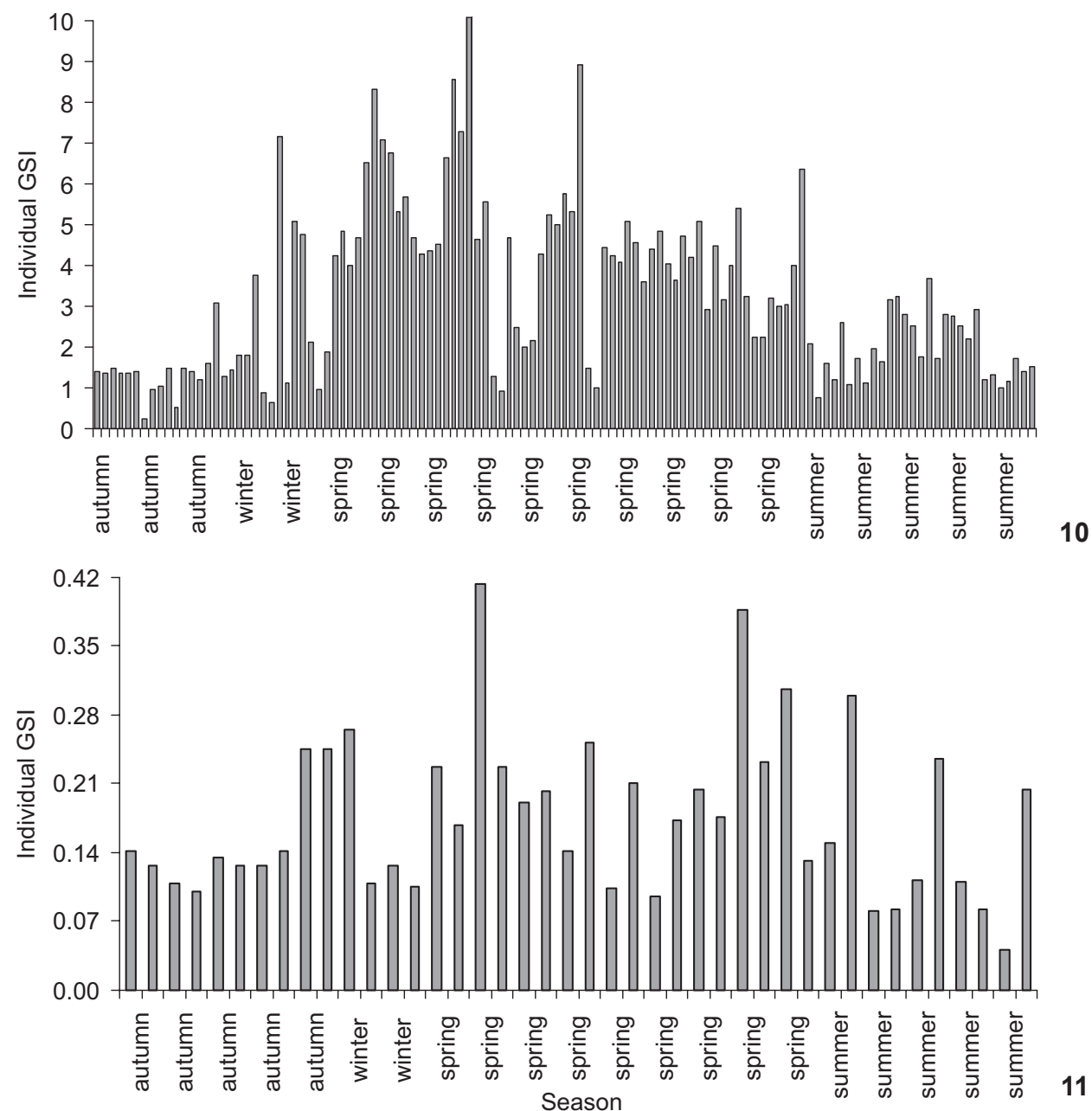

11

Figures 10-11. Seasonal distribution of the individual GSI values for females (10) and males (11) of A. lineatus in the Paranaguá Bay, state of Paraná. 

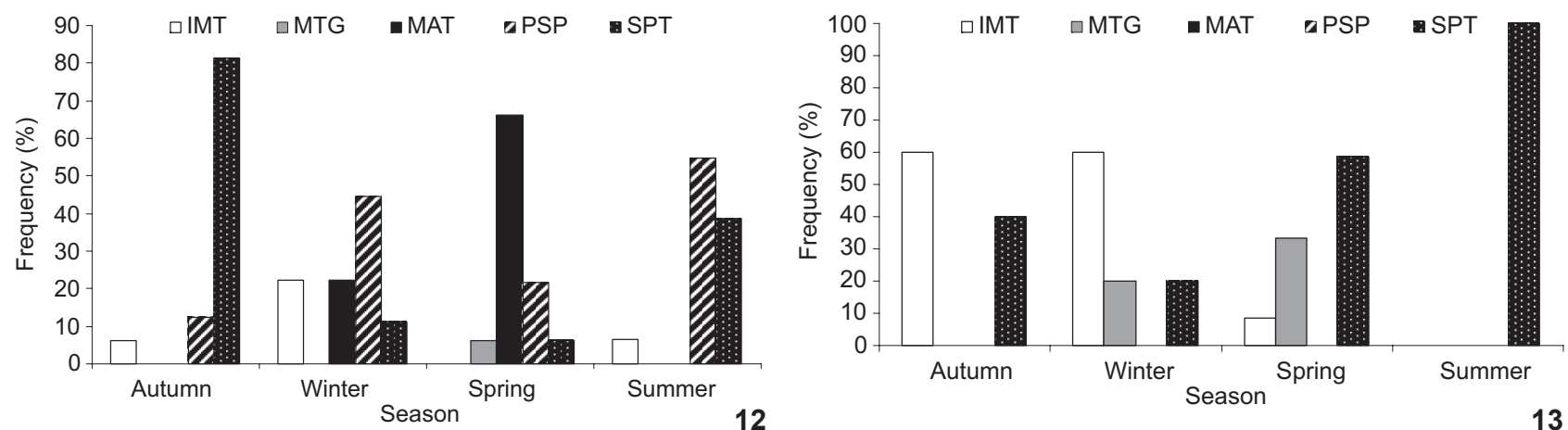

Figures 12-13. Seasonal distribution of the percentage frequency of the stages of gonadal development for females (12) and males (13) of $A$. lineatus in the Paranaguá Bay, state of Paraná. (IMT) Immature, (MTG) maturing, (MAT) mature, (PSP) partially spawned, (SPT) spawned/spent/recovered.
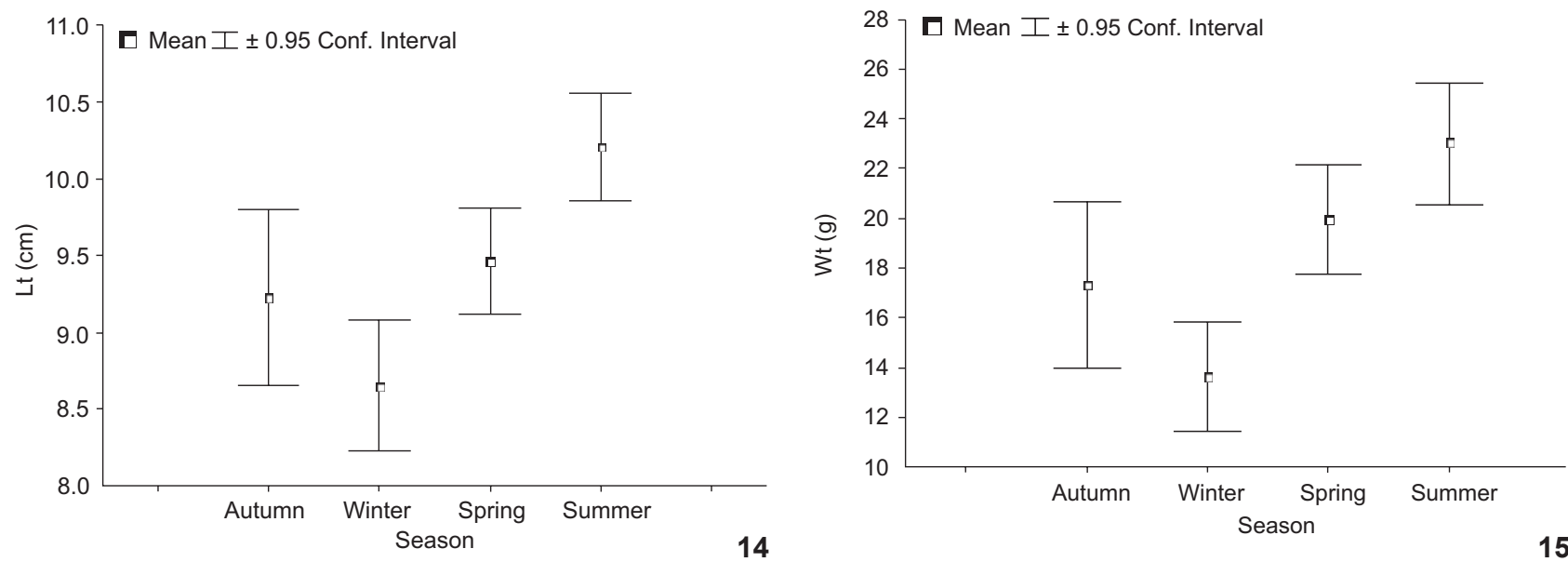

Figures 14-15. Seasonal variation in (14) total length and (15) total weight for the grouped sexes of $A$. lineatus individuals in the Paranaguá Bay, state of Paraná.

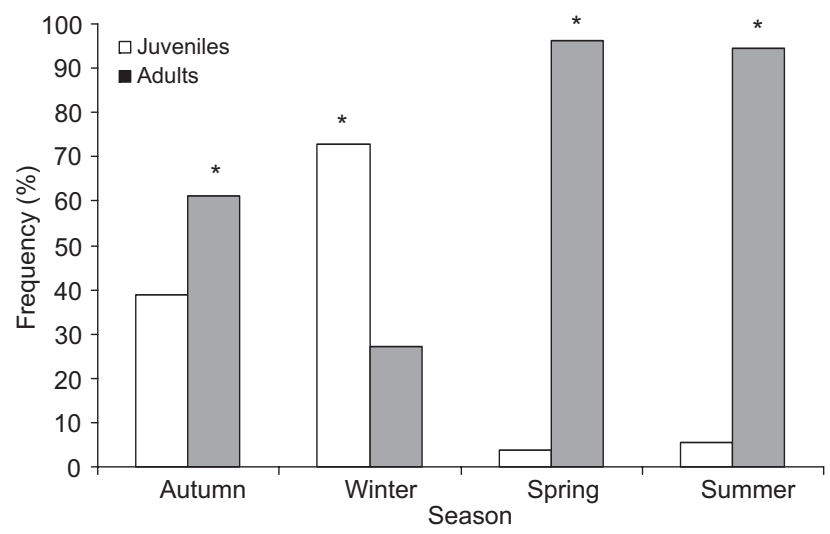

Figure 16. Seasonal ratio of juveniles to adults for the grouped sexes of $A$. lineatus in the Paranaguá Bay, state of Paraná. * significant values $(p<0.05)$.
Spring was the period of highest reproductive activity, confirmed through the distribution of GSI individual values and the seasonal distribution of the stages of gonadal development (both sexes). However, the verification of partially spawned and spent females throughout the cycle, especially in the summer months, demonstrates that $A$. lineatus exhibits synchronous ovarian development in many batches. This kind of ovarian development was reported by WоoтоN (1998) as common in environments where environmental factors fluctuate intensely, as is the case with estuarine ecosystems (Kupschus \& Tremain 2001, Miranda et al. 2002).

We considered batch spawning, defined from the partially spawned ovaries, to be a reproductive tactic to achieve greater reproductive success in the study area. According to VAzzoler (1996), the degree of variability and the quality of abiotic conditions, food availability and predation are among the various factors modulating reproductive tactics. 
Based on the analysis of the ratio of juveniles to adults, the recruitment period of $A$. lineatus occurs mainly during autumn, corroborating the findings of DANDO (1984) and LAZZARI et al. (2003), who reported an increase in captures of juvenile estuarine fish during summer and/or autumn.

The fact that $A$. lineatus females achieve larger sizes than males and exhibit a distinct weight-length relationship is in agreement with NiKoLsky (1963). According to the author, the most frequent forms of sexual dimorphism in fishes are differences in size and weight-length relationships. Among females, a larger body size is favored because it results in an increase in fecundity; by contrast, in males, size driven by sexual selection (SHINe 1990).

Besides the seasonal fluctuations found in individual GSI values, the distribution of percent frequency of gonadal development stages, the ratio of juveniles to adults, and other population parameters such as the size of individuals and the sex ratio in the period of greater reproductive activity also fluctuated. These fluctuations are likely a response to the reproduction and recruitment processes in the population of $A$. lineatus under study. According to Jobling (1995), the rise in temperature and the gradual increase in day length that starts in spring, associated with the greater availability of food in the summer months (Lowe-McConNell 1999), are the factors that usually determine the reproductive period and the recruitment of fish species in temperate and subtropical climates. Lange \& GReve (1997), studying different flatfish species, reported that temperature influences gonadal maturation, spawning period and the distribution pattern of these species.

According to DANDO (1984), the peak of reproductive activity of most estuarine species during the spring is related to a greater likelihood of offspring surviving in the seasons that follow, when there are more resources available. This assumption is corroborated by the studies of ChAVEs (1994, 1995, CHAVES \& Vendel (1997), Rocha et al. (2002), Schultz et al. (2002), Fávaro et al. $(2003,2005,2007)$, who reported that the spring is the period of greatest reproductive activity for the estuarine-resident species in the shores of Paraná (subtropical region). However, different results have been reported for estuarine species in the Brazilian tropical region (BARBIERI et al. 1991, Gomes et al. 1999 and Pessanha \& Araujo 2001). According to LoweMcConnell (1999), the reproductive period occurs at different times along the Brazilian coast, probably as a result of differences in the prevailing environmental conditions, both abiotic (temperature and photoperiod) and biotic (availability of adequate food for the early development stages).

In addition to the abiotic and biotic variables that modulate the distribution, activity and behaviour of fishes in estuaries, the intense anthropogenic activity developed in those environments should be regarded as having a major impact on the reproductive success of species, hence the preservation of fish stocks. Therefore, it is crucial to make available information on the reproductive biology of estuarine species. This is of paramount importance for the understanding of the dynamics of each population and for decision-making in species management. Such knowledge is equally important when it comes to the creation of laws regulating the exploitation of habitats and fisheries.

\section{LITERATURE CITED}

Azevedo, M.F.C.; C. Oliveira; B.G. Pardo; P. Martinez \& F. Foresti. 2007. Cytogenetic characterization of six species of flatfishes with comments to karyotype differentiation patterns in Pleuronectiformes (Teleostei). Journal of Fish Biology 70 (Suppl. A): 1-15.

Bailey, K.M.; A.A. Abookire \& J.T. Duffy-Anderson. 2008. Ocean transport paths for the early life history stages of offshorespawning flatfishes: a case study in the Gulf of Alaska. Fish and Fisheries 9: 44-66.

Barbieri, L.R.R.; J.V. Andreata; M.A. Santos; M.H.C. Silva; A.S.C. Sebilia \& R.P. Santos. 1991. Distribuição e ciclo de vida das espécies de peixes mais abundantes da Laguna de Marapendi, Rio de Janeiro, Brasil. Revista Brasileira de Zoologia 7 (3): 223-243.

Barletta, M.; A. Barletta-Began; U. Saint-Paul \& G. Hubold. 2005. The role of salinity in structuring the fish assemblages in a tropical estuary. Journal of Fish Biology 66: 45-72.

Berendzen, P.B. \& W.W. Dimmick. 2002. Phylogenetic relationships of Pleuronectiformes based on molecular evidence. Copeia 2002: 642-652.

Blaber, S.J.M. 2002. 'Fish in hot water': the challenges facing fish and fisheries research in tropical estuaries. Journal of Fish Biology 61 (Suppl. A): 1-20.

Brooks, S.; C.R. Tyler \& J.P. Sumpter. 1997. Egg quality in fish: what makes a good egg? Reviews in Fish Biology and Fisheries 7: 387-416.

Chaves, P.T.C. 1989. Hidratação pré-ovulatória em peixes: um caráter de origem marinha? Revista Brasileira de Zoologia 6 (3): 463-472.

Chaves, P.T.C. 1994. A incubação de ovos e larvas em Genidens genidens (Valenciennes) (Siluriformes, Ariidae) da Baía de Guaratuba, Paraná, Brasil. Revista Brasileira de Zoologia 11 (4): 641-648.

Chaves, P.T.C. 1995. Atividade reprodutiva de Bardiella ronchus (Curvier) (Peixes, Sciaenidae) na Baía de Guaratuba, Paraná. Revista Brasileira de Zoologia 12 (4): 759-766.

Chaves, P.T.C. \& A.L. Vendel. 1997. A reprodução de Stellifer rastrifer (Jordan) (Teleostei, Sciaenidae) na Baía de Guaratuba, Paraná, Brasil. Revista Brasileira de Zoologia 14 (1): 81-89.

Dando, P.R. 1984. Reproduction in Estuarine Fish, p. 155-170. In: G.W. PotTs \& R.J. Wootton (Eds). Fish reproduction: strategies and tactics. San Diego, Academic Press, 424p.

Dias, J.F.; E. Peres-Rio; P.T.C. Chaves \& C.L.D.B. Rossi-Wongtschowski. 1998. Análise Macroscópica dos Ovários de Teleósteos: Problemas de Classificação e Recomendações de 
Procedimentos. Revista Brasileira de Biologia 58 (1): 55-69. Dias, J.F.; C.B. Fiadi; H.L.N. Silbiger \& L.S.H. Soares. 2005. Reproductive and population dynamics of the Bay whiff Citharichthys spilopterus Günther, 1862 (Pleuronectiformes: Paralychthyidae) in the Mamanguá Inlet, Rio de Janeiro, Brazil. Neotropical Ichthyology 3 (3): 411-419.

Favaro, L.F.; S.C.G. Lopes \& H.L. Spach. 2003. Reprodução do peixe-rei, Atherinella brasiliensis (Quoy \& Gaimard) (Atheriniformes, Atherinidae), em uma planície de maré adjacente à gamboa do Baguaçu, Baía de Paranaguá, Paraná, Brasil. Revista Brasileira de Zoologia 20 (3): 501-506.

FÁvaro, L.F.; F.A. Frehse; R.N. Oliveira \& R. Schwarz Jr. 2005. Reprodução do bagre amarelo, Cathorops spixii (Agassiz) (Siluriformes, Ariidae), da Baía de Pinheiros, região estuarina do litoral do Paraná, Brasil. Revista Brasileira de Zoologia 22 (4): 1022-1029.

FÁvaro, L.F.; E.C. Oliveira \& N.F. Verani. 2007. Estrutura da população e aspectos reprodutivos do peixe-rei Atherinella brasiliensis (Quoy \& Gaimard) (Atheriniformes, Atherinopsidae) em áreas rasas do complexo estuarino de Paranaguá, Paraná, Brasil. Revista Brasileira de Zoologia 24 (4): 1150-1156.

Figueiredo, J.L. \& N. Menezes. 2000. Manual de Peixes Marinhos do Sudeste do Brasil - VI. Teleostei (5). São Paulo, Editora da Universidade de São Paulo, 116p.

Gomes, L.D.; F.G. Araújo; M.C.C. Azevedo \& A.L.M. Pessanha. 1999. Biologia reprodutiva dos bagres marinhos, Genidens genidens (Valencianes) e Cathorops spixii (Agassiz) (Siluriformes, Ariidae) na Baía de Sepetiba, Rio de Janeiro, Brasil. Revista Brasileira de Zoologia 16 (2): 171-180.

Gomes, I.D. \& F.G. Araujo. 2004. Reproductive biology of two marine catfishes (Siluriformes, Ariidae) in the Sepetiba Bay, Brazil. Revista de Biologia Tropical 52 (1): 143-156.

Guedes, A.P.P. \& F.G. Araujo. 2008. Trophic resource partitioning among five flatfish species (Actinopterygii, Pleuronectiformes) in a tropical bay in south-eastern Brazil. Journal of Fish Biology 72: 1035-1054.

Guedes, A.P.P.; F.G. Araujo \& M.C.C. Azevedo. 2004. Estratégia trófica dos linguados (Quoy \& Gaimard) (Actinopterygii, Pleuronectiformes) na Baía de Sepetiba, Rio de Janeiro, Brasil. Revista Brasileira de Zoologia 21 (4): 857-864.

IPARDES. 2001. Zoneamento da Área de Proteção Ambiental de Guaraqueçaba. Curitiba, Instituto Paranaense de Desenvolvimento Econômico e Social, 150p.

Joвling, M. 1995. Environmental Biology of Fishes. London, Chapman \& Hall, 455p.

Kupschus, S. \& D. Tremain. 2001. Associations between fish assemblages and environmental factors in nearshore habitats of a subtropical estuary. Journal of Fish Biology 58: 13831403.

Lana, P.C.; E. Marone; R.M. Lopes \& E. Machado. 2001. The subtropical estuarine complex of Paranaguá Bay, Brazil, p. 131-145. In: U. Seeliger \& B. KJerfre (Eds). Coastal marine ecosystems of Latin America. Berlim, Springer, 360p.
Lange, U. \& W. Greve. 1997. Does temperature influence the spawning time, recruitment and distribution of flatfish via its influence on the rate of gonadal maturation? German Journal of Hydrography 49: 251-263.

Lazzari, M.A.; S. Sherman \& J.K. Kanwit. 2003. Nursery use of shallow habitats by epibentic fishes in marine nearshore waters. Estuarine, Coastal and Shelf Science 56: 73-84.

Lowe-McConnell, R.H. 1999. Estudos Ecológicos de Comunidades de Peixes Tropicais. São Paulo, Editora da Universidade de São Paulo, 535p.

Lunardon-Branco, M.J. \& J.O. Branco. 2003. Alimentação natural de Etropus crossotus Jordan \& Gilbert (Teleostei, Pleuronectiformes, Paralichthyidae), na Armação do Itapocoroy, Penha, Santa Catarina, Brasil. Revista Brasileira de Zoologia 20 (4): 631-635.

MAACK, R. 1981. Geografia física do Estado do Paraná. Curitiba, BDT/UFPR/IBPT, 350p.

Mendonça, P. \& F.G. Araujo. 2002. Composição das populações de linguados (Osteichthyes, Pleronectiformes) da Baía de Sepetiba, Rio de Janeiro, Brasil. Revista Brasileira de Zoologia 19 (2): 339-347.

Miranda, L.B.; B.M. Castro \& B. Kjerfve. 2002. Princípios de Oceanografia Física de Estuários. São Paulo, Editora da Universidade de São Paulo, 417p.

Nelson, J.S. 1994. Fishes of the World. New York, WileyInterscience, $3^{\text {rd }}$ ed., 600p.

Nikolsky, G.V. 1963. The ecology of fishes. London, Academic Press, 351p.

Pardo, B.G.; A. MAChordom; F. Foresti; F. Porto-Foresti; M.F.C. Azevedo; R. Boñón; L. Sanches \& P. Martinez. 2005. Philogenetic analysis of flatfish (Order Pleuronectiformes) base don mitochondrial 16s rDNA sequences. Scientia Marina 69 (4): 531-543.

Patiño, R. \& C.V. Sullivan. 2002. Ovarian follicle growth, maturation, and ovulation in teleost fish. Fish Physiology and Biochemistry 26: 57-70.

Pessanha, A.L.M. \& F.G. Araújo. 2001. Recrutamento do peixerei, Atherinella brasiliensis (Quoy \& Gaimard) (Atheriniformes, Atherinopsidae), na margem continental da baía de Sepetiba, Rio de Janeiro, Brasil. Revista Brasileira de Zoologia 18 (4): 1265-1274.

Queiroz, G.M.N.; H.L. Spach; M. Sobolewski-Morelos; L.O. SanTOS \& R. Schwarz JR. 2006. Caracterização da ictiofauna demersal de duas áreas do complexo estuarino de Paranaguá, Paraná, Brasil. Biociências 14 (2): 112-124.

Quinn, G.P. \& M.J. Keough. 2002. Experimental design and data analysis for biologists. New York, Cambridge University Press, 520p.

Rocha, C.; L.F. Favaro \& H.L. Spach. 2002. Biologia reprodutiva de Sphoeroides testudineus (Linnaeus) (Pisces, Osteichthyes, Tetraodontidae) da gamboa do Baguaçu, Baía de Paranaguá, Paraná, Brasil. Revista Brasileira de Zoologia 19 (1): 57-63. Schultz, Y.D.; L.F. Favaro \& H.L. Spach. 2002. Aspectos 
reprodutivos de Sphoeroides greeleyi (Gilbert) (Pisces, Osteichthyes, Tetraodontidae), da gamboa do Baguaçu, Baía de Paranaguá, Paraná, Brasil. Revista Brasileira de Zoologia 19 (1): 65-76.

Schwarz Jr. R.; A.C.N.P. Franco; H.L. Spach; V. SARPedonti; H.A. Pichler \& G.M.N. Queiroz. 2006. Composição e estrutura da ictiofauna demersal na Baía dos Pinheiros, Paraná. Brazilian Journal of Aquatic and Technology 10 (1): 27-39.

SHINE, R. 1990. Proximate determinants of sexual differences in body size. American Naturalist, 135: 278-283.
VAzzoler, A.E.M. 1996. Biologia da reprodução de peixes teleósteos: teoria e prática. Maringá, Editora da Universidade Estadual de Maringá, 169p.

West, G. 1990. Methods of assessing ovarian development in fishes: a review. Australian Journal of Marine and Freshwater Research 41: 199-222.

Wooton, J.R. 1998. Ecology of teleost fishes. New York, Kluwer Academic Publishers, $2^{\text {nd }}$ ed., 386p.

ZAR, J.H. 1999. Biostatistical analysis. New Jersey, Prentice Hall, $4^{\text {th }}$ ed., 929 p.

Submitted: 02.IX.2009; Accepted: 22.V.2010.

Editorial responsibility: Rosana Mazzoni 